being 22.4 per cent.; so that these discases are to a very great de. gree complementary to each other.

\title{
RUPTURE OF THE UTERUS-RECOVERY.
}

By Benjamin Cughina, M.D., Dorchuster.

[Communicated for the Boston Medical and Surgical Journal.]

November 9 th, 1859 , I was called to see, in consultation with Dr. J. H. Warren, of Neponset, Mrs. K., Irish, aged about 32, then in labor with her first child. The patient had been in labor for a long time, the os uteri was fully dilated, and the membranes were broken, but the child had made no advance. It was deemed best to turn and deliver. This was accomplished only after reducing tho size of the head by perforation through the "foramen magnum." The patient recovered without any trouble.

Dec. 9th, 1860, I was again called by Dr. Warren to this same woman, again in labor. I saw her between 9 and 10 o'clock, P.M. At 6, P.M., her pains, after long continuance, had suddenly ceased. There had been vomiting, with extreme prostration. Stimulants had been freely given. On laying my hand upon the abdomen, I felt what seemed to me to be some part of the child, with only the abdominal walls interposed between it and the hand. Examining per vaginam, I could just reach the head. The child was turned and extracted, as before, after perforation through the foramen mag. num. The placenta followed without any difficulty.

Wishing to verify our diagnosis, I again passed my hand into the vagina, and found a rupture in the side of the uterus, which extended completely through the neck. Through this rupture I passed my hand to the umbilicus, where it could be distinctly felt by Dr. Warren. I could feel and grasp the intestines. The patient recovered, and her case was published by Dr. W. in this Jounnal for March 21, 1861.

I did not again see the patient until the latter part of last May, when curiosity led me to look her up, to know if she had been again pregnant. I found her expecting to be confined within a weck or two. She requested my attendance, which I promised her, Dr. Warren having joined the Army. I directed her, on the first symptoms of labor, to see that the rectum was evacuated, and to send for me immediately.

June 21st, 1863, I saw her at 2 o'clock, P.M. The os uteri was well dilated, and the pains were just commencing. The membranes were broken. On examination, I found the funis in the vagina, but could not reach any part of the child. Aided by Dr. Blanchard, of Neponset, I etherized the patient and proceeded to turn. On passing my hand I felt, first the funis, sccondly the hand, and lastly the head. The arm was lying by the side of the head. I brought 
down the feet, but found much difficulty in extracting the hips, and still more in bringing the shoulders. This having, however, been accomplished, I perforated the head through the foramen magnum, and delivered the patient of a child weighing between nine and ten pounds. She recovered without any untoward symptom.

I am unable to give the exact dimensions of this woman's pelvis, but can only say it was so contracted that $I$ am convinced by no possibility could a living child, of the above-named weight, have been born.

This is the second case of rupture of the uterus to which I have been called. The first was fatal.

August 28th, 1863.

\section{AMPUTATION IN GUN-SHO'T FRACTURES OF THE 'THIGH.}

[Tranglated for the Boston Med. and Surg. Jour. from the " Traite de Chirurgie d'Armée," par L. Legouest.

Bx David W. Chesvir, M.D., Boston.

SECOND PAPER.

On the Time of Amputation, whether Immcdiate, Mcdiate, or Ulterior. On the general Results of Amputation; and also an Inquiry into the relative Success of Amputations in the English and French Forces in the Crimea.

\section{TRANSLATION.}

NoT only is it important to determine the indications for amputation, but also the proper moment to operate. Amputations have always been divided into those done immediately, or a very little while, after the injury, and those done at a period more or less remote from the accident. The following table, which we borrow from Jules Roux, serves to explain the expressions mado use of by different authors to designate the time when amputations are performed.

\begin{tabular}{|c|c|c|c|}
\hline Authors. & lst Period. & $2 d$ Pcriod. & 3d Pcriod. \\
\hline $\begin{array}{l}\text { Faure et Boucher. } \\
\text { Inurcy. } \\
\text { Dupuytren. } \\
\text { Boyer. } \\
\text { S. Cooper. } \\
\text { Velpenut. } \\
\text { Vidal (de Cassis). } \\
\text { Baudens. } \\
\text { Lisfranc. } \\
\text { Nélanton. } \\
\text { Malguipne. } \\
\text { Fenwick. } \\
\text { Alcook. } \\
\text { Sédillot. } \\
\text { Denonvilllers et Gelin. } \\
\text { Legouest. } \\
\text { H. Lurrey. } \\
\text { J. Roux. }\end{array}$ & $\begin{array}{l}\text { Immediatc. } \\
\text { Immediate or prima- } \\
\text { Primary. } \\
\text { On tlie spot. } \\
\text { Immedilite. } \\
\text { Immediate. } \\
\text { Immedlate. } \\
\text { Primary. } \\
\text { Primary or immedi- } \\
\text { Immedlate. } \\
\text { Imminediate. } \\
\text { Primary. } \\
\text { Primary. } \\
\text { Immediate. [nte. } \\
\text { Primary or immedi- } \\
\text { Imnediate. [ry. } \\
\text { Immediate or prima- } \\
\text { Immediate or prim'y. }\end{array}$ & $\begin{array}{l}\text { Secondary or late. } \\
\text { Consecutive. } \\
\text { Consecutive. } \\
\text { Late.* } \\
\text { Consecutive. [dary. } \\
\text { Consecutive or secon- } \\
\text { Secondary. } \\
\text { Consecutive. [utive. } \\
\text { Secondary or consec- } \\
\text { Consecutive. } \\
\text { Secondary. } \\
\text { Secondary. } \\
\text { Intermediary. } \\
\text { Retnrded. [dary. } \\
\text { Consecutive or secon- } \\
\text { Mediate. } \\
\text { Consecutive. } \\
\text { Medinte or Sccon- } \\
\text { dary phases } \\
\text { Phlegmonous, or of } \\
\text { Osteo-myelitis. }\end{array}$ & $\begin{array}{l}\text { Secondary. } \\
\text { Ulterior. } \\
\text { Late or ulterlor. } \\
\text { Late. } \\
\text { Ulterior. } \\
\text { Consecutive. }\end{array}$ \\
\hline
\end{tabular}

- Tardive. 